\title{
Personal Names as Neglected Sociolinguistic Resource: Use of English in Botswana
}

\author{
Sheena F. Gardner \\ University of Warwick
}

\begin{abstract}
Studies of the use of English around the world take a variety of forms, but most take a narrow view of language that excludes personal names and thus fail to gain the fuller perspective that names provide. This study draws upon descriptions of the use of English in Botswana and a recent questionnaire study of personal names and shows parallels between early contact with English and the use of Christian names. Although English is increasingly the language of official and educational communication in Botswana, the practice of giving English names is declining. Moreover, attitudes towards English names are more ambivalent than the positive attitudes reported for English generally.
\end{abstract}

You may see no rivers on the ground but we keep the rivers inside us. That is why all good things and all good people are called rain. Sometimes we see the rain clouds gather even though no cloud appears in the sky. It's all in the heart. Bessie Head $(1984,168)$ in Lewis (1998)

\section{Introduction}

Investigations into the role of English around the world concern the history of English in particular countries, the domains in which it is used, attitudes towards English, and regional varieties of English (e.g., Schmied 1991; Andersson and Janson 1997). Such studies are limited in as far as they focus on a view of English that is restricted to a narrow definition of language that does not extend to proper names. Examples from English in Botswana will be used to demonstrate ways in which our understanding of the role of English within a community can be enhanced when English names and the practice of giving English names are also considered.

The role of English in Botswana has been given considerable scholarly attention (e.g., Andersson and Janson 1997; Essilfe 1997;

Names 47.2 (June 1999):139-156

ISSN:0027-7738

(c) 1999 by The American Name Society 


\section{Names 47.2 (June 1999)}

Nyati-Ramahobo 1991; Smieja 1996). In contrast, the study of names in Botswana has received little attention until recently ${ }^{1}$ (Gardner 1998; Mathangwane and Gardner 1998). These recent studies draw upon the results of a questionnaire distributed to University of Botswana students that produced a data set of the first and second given (not family) names of 4225 individuals, given over the last century. ${ }^{2}$

\section{English and English Names in Botswana}

The history of English in Botswana has been well documented, from its introduction by traders and missionaries more than a century ago, through the period of the British protectorate, when the country was known as Bechuanaland, to independence in 1966, to the present, where English and Setswana, ${ }^{3}$ the national language of the majority, are both widely used, often in complementary domains.

A historical perspective of naming practices in Botswana is presented in figure 1 , which shows a small percentage of those born around the turn of the century with English names, ${ }^{4}$ with numbers increasing for those born in the 1960s and 1970s, where more than $50 \%$ have at least one English name, around $35 \%$ of whom have both an English and an African name. Since then there has been a steady decrease; less than $25 \%$ of those born in the last ten years have an English name and around $15 \%$ have both an English and African name. ${ }^{5}$

Figure 1. Linguistic Origin of Names

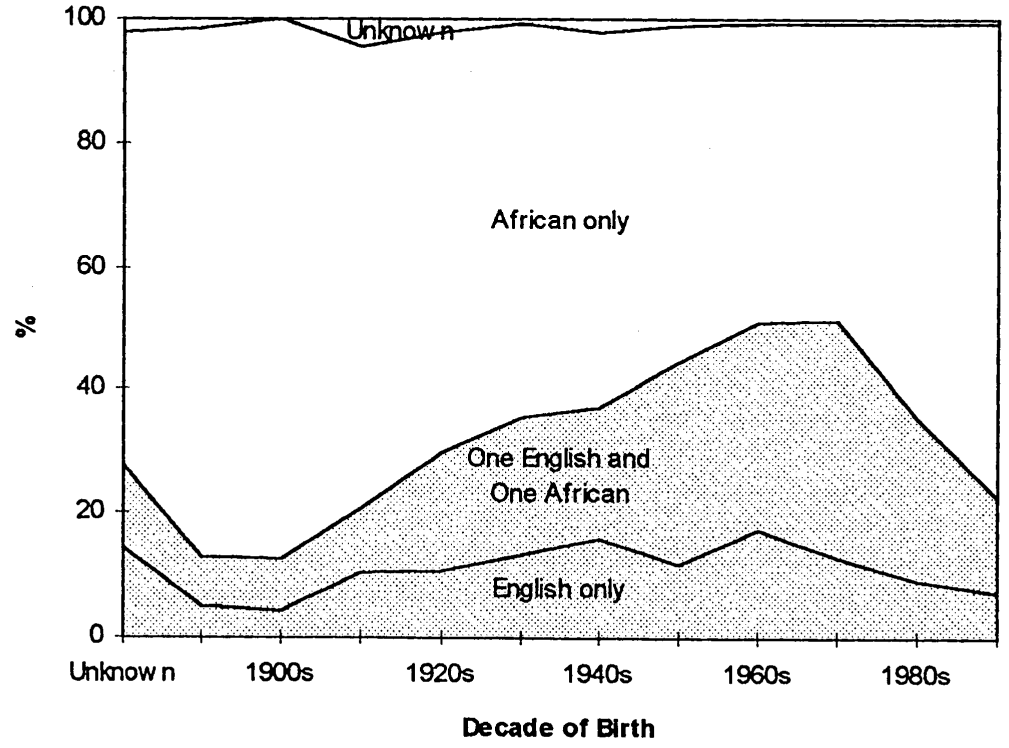




\section{Contact with English and English Names}

The name frequencies shown in figure 1 run parallel to the history of English in Botswana. Contact between English and Setswana began with small numbers of traders and missionaries in the 1820s (Andersson and Janson 1997, 170). The London Missionary Society was very active linguistically, translating the Bible into Setswana and thereby establishing a written medium (Andersson and Janson 1997, 170). English names appear to have been introduced initially as baptismal names. First generation Tswana converts to Christianity continued to be called by their Setswana names, but mission records and genealogies show that second generation Christians were referred to-at least formally-by two first names, one Setswana and one Christian (Comaroff and Comaroff 1991, 220). One assumes, therefore, that as Christianity took hold, English names became increasingly popular, particularly as they were used in combination with African names. English names never took over completely in Botswana, however, as they did elsewhere, such as in neighboring Namibia, where, as Saarelma-Maunumaa (1996) notes, after the introduction of Christianity, over $90 \%$ of Ovambo registered only one name, and that was a European name. Nevertheless, in Botswana, it seems that for many people initial use of English involved English Christian names.

The Accommodation of English and English Names

In a multilingual country such as Botswana, where 30 or more languages are spoken, the addition of one more-English - might not seem threatening, at least initially. Similarly, in a traditional African naming system, which allows for an individual to have many names, the addition of an English Christian name might initially be readily accepted. Herbert and Bogatsu (1990), in a study of Tswana names in South Africa, trace accounts dating back to the 1870 s which describe traditional practices of naming where children might be given a derogatory-protective name at birth to ward off evil; an infancy name given by the mother at initiation; a commemorative name (typically after a grandparent) at a name-giving ceremony; and later a kin name such as $M m a-X$, 'mother of $\mathrm{X}$ '). To these we might add praise names, given in a naming ceremony at the end of the wedding feast (mentioned by 


\section{Names 47.2 (June 1999)}

Ramphele 1996, 6-9); totem names, which were used in response to bureaucratic requests for a surname (Comaroff and Comaroff 1991, 220); and nicknames (e.g., Neethling 1994). With so many possible names, each with its own function in the life of an individual, the giving of a Christian name would certainly be significant, but it would not necessarily threaten the existing names or their ties to the local culture.

\section{English Names Today}

Botswana is now predominantly Christian and religion continues to influence name giving. Religious reasons account for $27 \%$ of all reasons given for choosing English names (table 1) and 18\% of all reasons given for choosing African names (table 2). The most common religious reasons given for English names are for baptismal purposes and to reflect religious commitment of the parents.

Table 1. Reasons Given for Choosing an English Name

$\begin{array}{lrrl}\text { Reason } & \text { N } & \% & \text { Examples } \\ \text { To Have an English Name } & 104 & 29 & \text { Albert, David, Dorcas } \\ \text { Religious, Typically for Baptism } & 100 & 27 & \text { Flora, Samuel, Ruth } \\ \text { Namesake: After Non-relative } & 53 & 15 & \text { Nelson, Elizabeth } \\ \text { Namesake: After Relative } & 33 & 6 & \text { Michael, Daniel, Laura } \\ \text { Attributes of Child } & 20 & 9 & \text { Shorty, Tiny, Jolly } \\ \text { School } & 19 & 5 & \text { Doris, Mavis, Alvin } \\ \text { Nicknames, Sports Names }_{\text {Family }}^{\text {a }} & 12 & 3 & \text { Shakes, Wire, Bricks } \\ \text { Circumstances at Birth } & 10 & 3 & \text { Patience, Queen, Lucky } \\ \text { Expectations of Child } & 6 & 2 & \text { Comet, Synod , Victoria } \\ \text { Other } & 3 & 1 & \text { Nurse } \\ \text { Total } & 3 & 1 & \text { John }\end{array}$

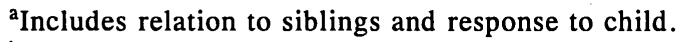

${ }^{b}$ Born when Synod was meeting.

${ }^{\mathrm{c} B o r n}$ near Victoria Falls.

Many English names are perceived as "Christian" names, such as Lucy and Dorcas, even though they may have no connection with the Bible, and other names, such as Psalm and Rejoice, are seen as "meaningfully" Christian. 
Table 2. Reasons Given for Choosing an African Name

\begin{tabular}{|c|c|c|c|}
\hline Reason & $\mathrm{N}$ & $\%$ & Examples \\
\hline $\begin{array}{l}\text { Family: Relation to } \\
\text { Sibling; Response } \\
\text { to Child }\end{array}$ & 231 & 31 & $\begin{array}{l}\text { Chawapiwa 'whatever you have been given'. } \\
\text { Fourth girl in family, so accept it. } \\
\text { Ookeditse 'to increase'. Boys were few in the } \\
\text { family; he increased the number. }\end{array}$ \\
\hline $\begin{array}{l}\text { Religion-Praise } \\
\text { God }\end{array}$ & 111 & 15 & $\begin{array}{l}\text { Mpho 'gift'. Regarded as gift from God. } \\
\text { Keolebogile 'I thank God'. Thanking God for } \\
\text { giving a daughter. }\end{array}$ \\
\hline Other Religious & 25 & 3 & $\begin{array}{l}\text { Baitshephi 'believers, saints'. Born into a } \\
\text { Christian family. } \\
\text { Marata 'Martha'. Biblical name. }\end{array}$ \\
\hline Attributes & 87 & 12 & $\begin{array}{l}\text { Sennye 'tiny'. Very small at birth. } \\
\text { Mmabontle 'somebody beautiful'. "I was } \\
\text { very ugly as a baby so my parents gave me } \\
\text { this name so at last I became better." }\end{array}$ \\
\hline $\begin{array}{l}\text { Namesake: After } \\
\text { Relative }\end{array}$ & 78 & 10 & $\begin{array}{l}\text { Polelo 'story'. After grandmother. } \\
\text { Mokgadi 'thirsty one'. After grandfather. }\end{array}$ \\
\hline $\begin{array}{l}\text { Namesake: After } \\
\text { Non-relative }\end{array}$ & 12 & 2 & $\begin{array}{l}\text { Sobhuza '?' After King Sobhuza of } \\
\text { Swaziland. } \\
\text { Sikwane '?' Name of village that his great } \\
\text { grandfather came from. }\end{array}$ \\
\hline Expections of Child & 68 & 9 & $\begin{array}{l}\text { Monkgogo 'someone who will help me, } \\
\text { especially later; for a blind parent, you will } \\
\text { be her guide'. "My grandmother wanted a } \\
\text { grandaughter badly as she had grandsons and } \\
\text { I was the one to guide her." } \\
\text { Onkemetse "he is my advocate'. To defend } \\
\text { parents in time of trouble. }\end{array}$ \\
\hline $\begin{array}{l}\text { Reflecting Social } \\
\text { Tensions (Names as } \\
\text { pointers) }\end{array}$ & 47 & 6 & $\begin{array}{l}\text { Wananani 'be cooperative'. She was born } \\
\text { when her father was not on good terms with } \\
\text { his brother. } \\
\text { Kotihao 'punishment'. "This came from rela- } \\
\text { tives. They said my father was punished for } \\
\text { marrying a woman from another tribe." }\end{array}$ \\
\hline $\begin{array}{l}\text { Circumstances at } \\
\text { Birth }\end{array}$ & 44 & 6 & $\begin{array}{l}\text { Etsiletlala 'drought, famine'. Born during } \\
\text { hunger period. }\end{array}$ \\
\hline $\begin{array}{l}\text { Family Events } \\
\text { Around Birth }\end{array}$ & 20 & 3 & $\begin{array}{l}\text { Selelo 'cry over something'. Father died be- } \\
\text { fore she was born. }\end{array}$ \\
\hline $\begin{array}{l}\text { Events Around } \\
\text { Pregnancy }\end{array}$ & 15 & 2 & $\begin{array}{l}\text { Mmanoga 'snake's mother'. Snakes fright- } \\
\text { ened her mother when pregnant. }\end{array}$ \\
\hline $\begin{array}{l}\text { Nicknames, Sports } \\
\text { Names }\end{array}$ & 6 & 1 & $\begin{array}{l}\text { Sputta 'joking by hitting lightly'. Enjoyed } \\
\text { boxing and was in boxing club at school. } \\
\text { Tsetse "No meaning." Used in early years } \\
\text { and stuck. }\end{array}$ \\
\hline Other & 6 & 1 & $\begin{array}{l}\text { Ngoni 'mercy'. Grandmother could not pro- } \\
\text { nounce name, so translated it into Kalanga. }\end{array}$ \\
\hline Total & 750 & & \\
\hline
\end{tabular}




\section{Names 47.2 (June 1999)}

The attitudes expressed towards Christian names vary (Mathangwane and Gardner 1998), from reflecting a deep love for the Church and what it stands for, to expressing dismay at the way English names "with no meaning" are given. For example, a priest may simply decide on the Christian name for a child, or may give a list of names from which a child may choose a name-with no real guidance on the names, other than that they have religious significance.

Such disparate attitudes reflect the conflict between two naming practices: the Christian practice of choosing from a small name pool with little attention to meaning, and the African practice, where semantically transparent names tell their own story. (See Gardner 1998; Herbert and Bogatsu 1990; and de Klerk and Bosch 1995 for further details and discussion.) Batswana continue to give names for religious reasons, but the majority of these are now in local languages.

\section{Education and Urbanization}

Even though the use of English is on the decline in the religious domain, it is of considerable importance today in the domains of education, government, commerce and the media, even more so than it was before independence.

\footnotetext{
Soon after independence in 1966 a program for universal education was launched, and with English in the curriculum from the first year, and the medium of instruction from year 5 , the number of people who came into contact with English increased dramatically. Today almost the entire younger generation is acquainted with English. (Andersson and Janson 1997, 171)

The official point of view...has been and is very clear: proficiency in English is necessary for progress and should be encouraged in all possible ways. (Janson and Tsonope 1991, 75)
}

Although English language instruction does not start officially until year 5 in the curriculum, some children acquire an English name upon starting school, reinforcing the notion of English as a valued educational commodity.

In our study, $5 \%$ of the reasons given for having an English name relate to the importance of English names for school purposes (table 1). A further $3 \%$ relate to nicknames or sports names among teenagers (e.g., Shakes, Rocky). In comparison, no one reported taking an African 
name for school purposes and only $1 \%$ of African names were given as nicknames or sports names. (However, since this study did not specifically ask for nicknames, these numbers may be low.)

Several respondents commented upon the practice of taking an English name later in life, usually in adolescence, simply to have an English name, thus demonstrating that part of the semiotic value of names is their linguistic origin. Names may "mean" differently from other signs (e.g., see discussion in Hidiroglou-Zahariades 1997, 190192); English names, however, are part of English rather than universal, as a narrow view of language, such as that expressed by Crystal (1988, 37) would suggest: "Proper names aren't part of any one language; they are universal."

Some people with only an English name choose to take an African name in adolescence. Such choices are generally not made with respect to the specific names but to the language and culture of the names, suggesting that strong allegiance to both languages exists. As Smieja $(1996,4)$ says

There is a double allegiance towards English and Setswana, which implies some sort of conflict structure or at least a competitive situation between the two...languages.

Andersson and Janson (1997, 173) suggest that English dominates as a written language, while Setswana is used for most oral communication. What is emerging is a picture of languages in conflict: of ruralurban differences and private-public differences. A similar conflict emerges from the contact of traditional African naming practices, embedded in extended family units on the one hand with naming practices demanded by modern bureaucracy and urbanization on the other. Unique names are being replaced by shared names to accommodate both the need for early registration of births (perhaps before young urban families can return to their villages to choose names), and registration that requires a first name and a family name that do not change over the person's lifetime (Gardner 1998; Herbert and Bogatsu 1990; Suzman 1994). Data from the present study suggest that $51 \%$ of girls and $65 \%$ of boys born today have a name unique to their cohort, a change in uniqueness from approximately $60 \%$ of the children born in 


\section{Names 47.2 (June 1999)}

the 1970 s- 1980 s, approximately $72 \%$ of the children born in the 1940 s1960 s, and approximately $95 \%$ of those born at the turn of the century (Gardner 1998).

An examination of namesakes shows strong connections between African names and grandparents as namesakes versus English names and less traditional namesakes. There were more African names after grandparents, and more English names after cousins, aunts and uncles, but in both cases naming after relatives was important.

Other namesakes motivated English names considerably more than African names: $15 \%$ for English names versus 2\% for African names. These include friends and associates, such as Antoinette, "after a nun who used to teach my father," and internationally famous people such as Nelson Mandela, Queen Elizabeth II, and Bryan Adams. This practice reinforces the association of outside influences and English. There are famous, well-respected Batswana whose names could be used as namesakes and it is not clear why this does not happen with any regularity. It may be, however, parallel to the official attitudes and policies reported for Setswana:

In comparison [to English], the official attitude to Setswana can best be described as benign neglect.... [It] has a comparatively weak position in the school curriculum... and more importantly there are virtually no rewards for proficiency in Setswana in urban life. (Janson and Tsonope 1991, 75)

\section{Attitudes Towards English and English Names}

In Botswana, the attitude toward English is generally very positive:

[M]ost people seem to have fewer reservations about [English] than about their mother tongue, Setswana. English is very much seen as part of modern life and social success, while Setswana is often perceived as parochial and uninteresting.... 'The more the better' seems to be the general opinion about English. (Andersson and Janson 1997, 174)

The view of English as connected to modern life and social success is reflected in naming since the main reason given for choosing an English name (table 1) was simply to have an English name (29\%). This was desirable for reasons associated mostly with the prestige that results from the important role of English in society, in education, in government and in dealing with the rest of the world. However, while the role 
of English in general is going from strength to strength, the same is not true of English names as shown by the decline from $50 \%$ with at least one English name at the time of independence in 1966 to less than $25 \%$ today (figure 1).

These contrary perspectives are clearly expressed in the attitudes of university students towards English names (Mathangwane and Gardner 1988). Where Janson and Tsonope (1991) found that "there was no trace of a negative attitude towards English as such" and explain this by the fact that "the language was never connected with colonialism, or with improper Western dominance" (112), some students in our studyrightly or wrongly-associated English names with both colonialism and improper Western dominance. ${ }^{6}$ Specific negative attitudes frequently expressed in our study referred to the fact that English names have no meaning, that English names can be difficult for non-English speaking grandparents to pronounce and that the use of English names suggests lack of pride or loss of a sense of identity when one does not use the local names.

\section{Social and Family Relationships}

The influence of the African practice of giving meaningful names is noticeable in the English names chosen in areas related to religion, to the family and to society's expectations for a child. Many African names refer to a child's position in the family and to the extent to which the child was desired by its parents; these account for $31 \%$ of the reasons given for choosing an African name (as opposed to only $3 \%$ of the reasons for choosing an English name). Similarly, African names were chosen more often (9\% to $1 \%$ for English names) to express parental expectations and to mark family events such as the death of a close relative (tables 1 and 2). These practices suggest that English is used more in public domains, while African languages are used more in private domains. This finding supports research on the use of English in public domains as well as research on the extent of English-Setswana code-switching as related to interlocuters. Setswana-speaking students code-switch extensively with fellow students, less so with siblings and parents and not at all with grandparents (Andersson and Janson 1991, 46). 
It is also worth noting that some naming practices apply only to African names; for instance, giving protective names to ward off misfortune, such as Mobelong 'secret', given "because [through] witchcraft they might kill or do her harm" and using names as pointers (Suzman 1994) to regulate social behavior (table 2). These practices appear to be dying out, which may explain their lack of transfer to English, but they are also examples of linguistic practices that may not emerge from sociolinguistic studies that focus on narrow definitions of language.

\section{The Future}

The ambivalence surrounding English names reflects a conflict between English and Setswana names. While 52\% of respondents in our study predicted that English names would be used more in the future, $42 \%$ predicted that African names would be dominant, and only $6 \%$ predicted a balanced use of English and African names (Mathangwane and Gardner, 1998).

These conflicting attitudes are among the forces that have given rise to the English names of Botswana. As Schmied suggests,

[O]ne 'remedy' for improving attitudes towards English, especially among those who associate English with the colonial past or regard English as an evil influence which necessarily leads to Westernization, is the recognition of African varieties of English as pedagogical and sociolinguistic models. $(1991,171)$

With the English language the principles of "internationalism implies intelligibility" and "identity implies individuality" (Crystal 1994, 113) compete; where names are concerned in Botswana, "identity implies individuality" is clearly gaining the upper hand. This is reflected not only in the recent increase in African names, but also in the use of new Botswana English names.

\section{Botswana English Names}

In addition to "standard" English names, English names in Botswana include variants of standard English names, standard English words used as names, translations of African names into English, Setswana English names, and foreign names of Indo-European or Semitic origin. 


\section{Standard English Names}

The names that are popular in Botswana are unique to that society. Some, such as Elizabeth and John, have been popular throughout the century, while others have been more popular at particular times; Violet, for example, was popular only in the 1940s. Most of the names would be recognized as standard English names around the world. Some of the more popular English names in Botswana are shown in table 3.

Table 3. Popular Names in Botswana

\begin{tabular}{|c|c|c|c|}
\hline \multicolumn{2}{|c|}{ Male } & \multicolumn{2}{|c|}{ Female } \\
\hline John & Joseph & Elizabeth & Dorcas \\
\hline Samuel & Michael & Annah & Veronicah \\
\hline Jacob & David & Violet & Maria \\
\hline Peter & Daniel & Mary & Ruth \\
\hline James & George & Grace & Gladys \\
\hline Patrick & Isaac & Martha & Agnes \\
\hline Moses & Simon & Josephine & Florence \\
\hline Lucas & Kenneth & & \\
\hline Solomon & Stephen & & \\
\hline Phillip & William & & \\
\hline
\end{tabular}

\section{Variants of Standard English Names}

English names in Botswana may differ from English names in other countries in their spelling, pronunciation, meaning, significance, or a combination of these. At one extreme, they are simply variants of English names recognised around the world. For example, many names that end in spelled $a$ in most English-speaking countries end in $a h$ in Botswana, e.g., Dorah, Florah, Emmah, Lindah, Sylviah, Hildah, Annah and Idah. The reason for such variants is not clear. The names cannot be traced back to standard missionary texts and may simply have arisen by analogy with Sarah and Jonah, as suggested by Spencer (1997).

Differences in pronunciation are more easily explained by a comparison of the sound systems of the two languages in contact. English names pronounced "in Setswana" include Matthews [mætuz] and Ruth [rut], where standard English $/ \theta /$ is realised as a [t] sound. Despite 
differences in pronunciation or spelling, the English names would be recognizable as such outside Botswana.

English names may acquire new meaning or significance in Botswana; the name Ruth, for instance, became popular as the name of the English wife of the president and has acquired a national significance unique to Botswana.

\section{Standard English Words used as Names}

A large number of English words, many common nouns not widely used as names in other Englishes, become names in Botswana. Examples are Queen, Story, Comet, Jolly, Toronto, Wires, Shakes, even Hey and You. In Botswana many such names are incorporated into the African naming system and tend to reflect the circumstances at a child's birth or a child's physical characteristics.

These names combine an African way of naming with English language resources. One reason for this practice is offered by Pongweni (1983) in his discussion of Shona names; it appears to be as relevant for the Batswana as it is for the Shona:

Under western (particularly English) influence, Shona parents initially began to give their children Christian names...but these were soon found lacking in expressiveness. The culture-bound practice of giving loaded names to children was so much with us that...English words were picked...from the dictionary, and...used as names for children: the intent remained the same; but the medium of expressing it changed. (7-8)

\section{Translations of African Names}

A further consequence of giving meaningful names is seen when English names are given as translations of African names. For example, a child may be called Joyce or Comfort to express the meaning of the Setswana names Boitumelo 'happiness' or Kgomotso 'comfort'. Pongweni $(1983,16)$ points out that English names were often translations of Shona names, thus reinforcing the notion that this way of naming is African but the words used are English.

Although Biblical names are translated from English in the Setswana bible, and the practice of using English names when speaking English and Setswana names when speaking Setswana is observed (Mathangwane personal communication), in our data there was only one incidence of this: Jacob and Jakoba. 
Whether English names were translated into Setswana, or viceversa, or translation equivalents were found in the two name pools, the trend in our data was to give the English name as the first name and the Setswana translation as the second name.

\section{Setswana English Names}

Setswana English names include names such as Mmafat or Ngirl which are derived from English words by applying Setswana affixes. This derivational process also occurs in the lexicon generally (Magura $1990,86-7){ }^{7}$

\section{English Loan-Names}

In the previous sections English names were presented as if there were a stable pool of such names. However, just as foreign words are borrowed into English, possibly anglicized in the process, foreign names are borrowed and incorporated-to varying degrees-into the name pool. Where informants in our study were easily able to identify names as either indigenous African or not, and sometimes able to identify the origin of non-African names, most such non-African names were labeled simply "English," irrespective of their actual origin. Some "English" names in this category (to mention only several from those beginning with $A$ ) are Aaron, Abednico, Abel, Alphonse, Amos, Analiza, Angelina, Antoinette and Augustine. Whether these particular names should be included as standard English names or not is beside the point; they show that names perceived as "English" come from a number of sources, from many Indo-European and Semitic languages and they further suggest that names borrowed from such languages can be brought into the "English" name pool of Botswana. As such, they are different from the names that originate in other African languages and are brought into the African name pool of Botswana. They are unlike names that show a mixing of the two systems, such as Mmafat (English word 'fat' with Setswana affix) or Rut (English name with Setswana pronunciation), which were labeled "Setswana English" or "Tswanalised English" by respondents.

\section{English and Botswana English Names}

The Botswana English names in our study show quite clearly the direction of influence between the two languages. A comparison with the role of English is useful: 


\section{Names 47.2 (June 1999)}

In a situation of contact between two languages, the most prestigious one will influence the other. So far... English has only influenced Setswana to a modest extent. There are quite a few loan-words from English in Setswana.... But beyond the level of loan-words, English has at least not yet had any particular impact on Setswana. No English sounds have become integrated into the Setswana sound system, nor can any traces of English morphology or English syntax be found. (Andersson and Janson 1997, 174)

The evidence from the study of English names supports these findings. There are large numbers of English names widely used in Botswana, a parallel with the loan-words not only in extent but also in domain, and the examples of Setswana English all suggest that Setswana has had an impact on the pronunciation and morphology of English, rather than the other way round. All the English names of Botswana mentioned above, in different ways, bring together something indigenous and something from a foreign language. Such names in other contexts are viewed as compromises between different socio-political pressures, or between traditional rural values and newly acquired urban values, as well as compromises between semiotic systems (e.g., Konstantinov and Alhaug 1995). Further research might profitably explore the extent to which such names represent a compromise or accommodation in Botswana; how families adjust to the new naming systems over the generations; and in which domains such names are used, i.e., the parallels (if any) between code-switching and naming practices.

\section{Conclusion}

The evidence from Botswana argues that an understanding of the role of English in a country can be enriched by considering the English names found there. The initial contact with English surrounding the introduction of Christianity is augmented if the widespread influence of English Christian names is taken into account. While the role of English in Botswana has been increasing in importance since independence, the role of English names has been declining; where attitudes to English as an official language with a great deal of prestige in Botswana are exceedingly positive, a much greater ambivalence is expressed towards English names. To some extent this is explained by examining the domains in which English and English names are found; specifically by comparing public uses in education and intra-national communication to 
matters relating more closely to personal, group and national identity. Evidence from Botswana English names suggests that arguments for and against a Botswana English, or a Southern African English, can usefully be supplemented by evidence from English names.

Names are particularly useful in multilingual contexts such as those found in Botswana since they go beyond the typical points of contact usually considered in sociolinguistic studies-terms of address, to mention one often-cited example (see, e.g., Fasold 1984; 1990; Holmes 1992; Montgomery 1995).

Explanations for linguistic and onomastic changes can be sought in socio-political contexts. Despite rather different political histories, Botswana and its neighboring countries, specifically Namibia, South Africa and Zimbabwe show similar trends with respect to the role of English names.

This initial study argues not only for taking into account the role of English names in country or area studies of the role played by English generally, but also for taking English names into account in studies of the role of English internationally-something that is not generally done.

\section{Notes}

I am grateful to the Overseas Development Agency and the British Council for funding the research link between the Centre for English Language Teacher Education, University of Warwick and the English Department, University of Botswana, that made this research possible.

I would like to thank Julia Khan, Joyce Mathangwane and John Spencer for commenting on a previous draft of this paper and also the many colleagues and students in Botswana who participated willingly in this study and shared their views on naming.

1. Lawson (1987) lists two articles on naming practices of the !Kung Bushmen; Herbert and Bogatsu (1990) have written on Tswana names in neighboring South Africa.

2. Since third names were given only for three individuals, they were ignored in this study. The questionnaire asked students to name a maximum of 25 members of their immediate families. It asked for the sex, age, and relationship to the informant of each named person and it asked for the language of each name, its meaning and its significance. For the first nine names given it asked specifically for the reason(s) for giving the name, the context(s) of its use, and the age at which it was given. For the remaining 16 names it simply asked for additional comments. The final section was open-ended and asked about the respondents' perceptions of patterns of naming in their families, when (or if) English names appeared, and whether or not they expected English names to persist to future generations. 


\section{Names 47.2 (June 1999)}

3. Tswana is the root morpheme in the word for the country Botswana, the language Setswana, the language, and the people Batswana. Today's Botswana has a majority who speak Setswana as their first language and a significant minority whose first language is Ikalanga.

4. An "English name" is one consisting of one English name, two English names, or an English name plus a name whose origin is unknown to the informant. An "African name" is one consisting of one African name, two African names or one African name plus a name whose origin is unknown to the informant. "English" includes all Indo-European and Semitic names, the majority of which were English $(27 \%)$, followed by Afrikaans (.3\%) and twelve other languages. The majority of "African" names were Setswana (63\%), followed by Kalanga (4.5\%) and smaller numbers of twelve other African languages, mostly those of Botswana.

5. A similar trend is observed for Xhosa-speakers, with the move away from English names being more accelerated in urban rather than rural areas (de Klerk and Bosch 1995, 80).

6. It should be noted that these numbers were much smaller than those reported among students at the University of the Western Cape where around $30 \%$ of those with English names felt strongly negative about them for their association with oppression, domination and westernization, while around $20 \%$ were strongly positive (Neethling 1988 in de Klerk and Bosch 1995, 81).

6. Interestingly, the reverse phenomenon occurs in the United States where African names are used with endings modified to suit the English conventions of gender marking (Lieberson and Mikelson 1995, 944).

\section{References}

Andersson, L-G. and T. Janson. 1991. Languages and Language Use among Students at the University of Botswana. Marang 9:42-51. 1997. Languages in Botswana: Language Ecology in Southern Africa. Gaborone: Longman Botswana.

Arthur, J. 1997. "There Must be Something Undiscovered Which Prevents Us From Doing Our Work Well": Botswana Primary Teachers' Views on Educational Language Policy. Language and Education 11:225-241.

Crystal, D. 1988. The English Language. London: Penguin. . 1994. Which English-or English Which? In M. Hayhoe and S. Parker, eds., Who Owns English? Buckingham: Open University P, 108-114.

Comaroff, J. and J. Comaroff. 1991. Of Revelation and Revolution: Christianity, Colonialism, and Consciousness in South Africa. Chicago: U of Chicago P. 
de Klerk, V. and Bosch, B. 1995. Naming in Two Cultures: English and Xhosa Practices. Nomina Africana 9:68-87.

Essilfe, T. 1997. The Language Dilemma of Botswana. ms.

Fasold, R. 1984. The Sociolinguistics of Society. Oxford: Blackwell. . 1990. The Sociolinguistics of Language. Oxford: Blackwell.

Gardner, S.F. 1998. From Molelowakgotla through Michael to Mpho: the role of English from an onomastic perspective. Plenary presented at Language, Literature and Society: Paradigms and Pedagogies. A Conference in Honor of Bessie Head. U of Botswana, 17-19 June.

Head, Bessie. 1984. When Rainclouds Gather. London: Heinemann.

Herbert, R.K. and S. Bogatsu. 1990. Changes in Northern Sotho and Tswana Personal Naming Patterns. Nomina Africana 4:1-19.

Hidiroglou-Zahariades, A. 1997. L'Onomastique dans les lieux de divertissement. Onoma 33:189-221.

Holmes, J. 1992. An Introduction to Sociolinguistics. London: Longman.

Janson, T. and J. Tsonope. 1991. Birth of a National Language: The History of Setswana. Gaborone: Heinemann Botswana.

Konstantinov, Y. and G. Alhaug. 1995. Names, Ethnicity and Politics: Islamic names in Bulgaria, 1912-1992. Oslo: Novus P.

Lawson, E.D. 1987. Personal Names and Naming: An Annotated Bibliography. Westport, CT: Greenwood P.

Lewis, D. 1998. "Power, Representation and the Textual Politics of Bessie Head." Plenary presented at Language, Literature and Society: Paragidms and Pedagogies. A Conference in Honor of Bessie Head. University of Botswana. 17-19 June.

Lieberson, S. and K.S. Mikelson. 1995. Distinctive African American Names; an Experimental, Historical and Linguistic Analysis of Innovation. American Sociological Review 60:928-946.

Magura, B. 1990. Register as a Function of Contextualization: A Survey of the Southern African Variety of English. Marang 8:78-104.

Mathangwane, J.T. and S.F. Gardner. 1998. Language attitudes as portrayed by the use of English and African names in Botswana. Paper presented at Language, Literature and Society: Paradigms and Pedagogies. A Conference in Honor of Bessie Head. U of Botswana, 17-19 June. 


\section{Names 47.2 (June 1999)}

Montgomery, M. 1995. An Introduction to Language and Society. 2nd ed. London: Routledge

Neethling, S.J. 1988. Voorname in Xhosa. Nomina Africana 2:223-237. . 1994. Xhosa Nicknames. South African Journal of African Languages. 14:88-92

Nyati-Ramahobo, L.M. 1991. Language Planning and Education Policy in Botswana. Unpublished PhD thesis. U of Pennsylvania.

Pongweni, A.J.C. 1983. What's in a Name? A Study of Shona Nomenclature. Gweru: Mambo P.

Ramphele, M. 1996. A Life. Capetown: Philips.

Saarelma-Maunumaa, M. 1996. The Influence of Westernization on Ovambo Personal Names in Namibia. Nomina Africana 10:20-29.

Schmied, J.J. 1991. English in Africa: an Introduction. London: Longman.

Smieja, B. 1996. Language Shift, Cultural Identity, and Language Loyalty in Botswana. Paper presented at the national institute for research and development, U of Botswana, December.

Spencer, J. 1997. Personal Communication with Regarding Lepsius' 1863 Standard Alphabet for Reducing Unwritten Languages and Foreign Graphic Systems and Appleyard's Kafir Grammar.

Suzman, S. M. 1994. Names as Pointers: Zulu Personal Naming Practices. Language in Society 23:253-72. 